\title{
Semiótica de interface e interação de usuários
}

\author{
Semiotics of interface and users interaction \\ Rita de Cássia Romeiro Paulino, Richard Perassi, Francisco Antônio P. Fialho
}

semiótica, web, interface

\begin{abstract}
O objeto de estudo apresentado neste trabalho propõe uma análise semiótica de um visualizador de e-mails, como uma interface diferenciada com relação aos modelos já existentes para leitura, seleção e organização de e-mails. A teoria semiótica peirceana auxilia na interpretação e compreensão sobre as maneiras como os usuários interagem no ambiente web e permitem entender os processos de significação estabelecidos pelos usuários ao interagirem com uma interface web.
\end{abstract}

semiotic, web, interface

The object of study presented in this paper proposes a semiotic analysis of $n$ e-mail viewer, as an interface differentiated from existing models for e-mail reading, selection and organization. The peircean semiotic theory assists in the interpretation and understanding of the ways in which users interact with the web environment and allows understanding of the processes of significance set by users while interacting with a web interface.

\section{Introdução}

O objeto de estudo apresentado neste trabalho propõe uma análise semiótica de um "visualizador de e-mails", como uma interface diferenciada com relação aos modelos já existentes para leitura, seleção e organização de e-mails. A teoria semiótica peirceana auxilia na interpretação e compreensão sobre as maneiras como os usuários interagem no ambiente web (PEIRCE, 1972).

Os estudos em Semiótica permitem entender os processos de significação estabelecidos pelos usuários ao interagirem com uma interface web, porque como uma lógica dos processos significação, a Semiótica é instrumento adequado para análise dos processos e procedimentos mentais, que são expressos pelos usuários ao interagir em um website. Pois, uma vez tomados como processos de representação, essas interfaces têm como centro a dinâmica da significação ou representação interativa e o conceito de signo. Segundo Charles S. Peirce (1972), o signo é o elemento básico da representação ou significação, sendo que ele o considera como um elemento que permite a relação entre um objeto (da representação) e um interpretante (significado possível ou factual).

Em geral, o usuário web é abdutivo, considerando o conceito de abdução proposto por Peirce (Ghizzi, 2002), porque trabalha com hipóteses abdutivas sobre como interagir ou navegar, passando em seguida para um processo de tentativa e erro, durante o qual testa e corrige, o que for necessário.

Para Peirce (1972) o signo é "algo que, sob certo aspecto ou de algum modo, representa alguma coisa para alguém". No caso do agente humano, o signo é uma unidade conceitual que reside na mente do indivíduo que, para se formar, passa por três categorias de um processo de significação.

A primeira é denominada de "primeiridade", sendo a categoria que aciona no indivíduo, ou seja, nesse primeiro, a percepção com relação às qualidades intrínsecas aos objetos, promovendo, por exemplo, a sensação de calor.

A segunda é denominada de "secundidade", porque determina o momento em que a consciência é atraída para fora da sensação, estabelecendo o segundo como o elemento ou as 
condições que determinaram a primeiridade. Assim, são estabelecidas as associações de causa e efeito entre dois fenômenos ou objetos, como a relação entre o calor e o sol ou o calor e o fogo.

A terceira categoria é denominada de "terceiridade" porque estabelece um terceiro elemento mediador entre a primeiridade e a secundidade. Esse terceiro elemento cujo caráter é conceitual estabelece as relações simbólicas, mais complexas e sofisticadas, permitindo interpretações e nomeações do tipo: "o fogo é quente porque produz calor".

\section{A Semiótica da Navegação pela Web.}

Ao se deparar com a tela acesa do vídeo do computador, seja ao ligar o vídeo ou ao mudar de página durante a navegação na web, os estímulos luminosos que partem da tela alteram o estado psíquico do receptor/usuário, promovendo nesse um conjunto de sensações e sentimentos diferentes de seus estados anteriores. Essas mudanças de estado psíquico caracterizam as diferenças na categoria de primeiridade.

A alteração nas qualidades de suas sensações e sentimentos instiga o receptor/usuário a buscar a causa dessas mudanças, estabelecendo nele a consciência do segundo, fazendo-o reconhecer a luminosidade perturbadora do vídeo, e estabelecendo a interação característica da secundidade no processo de significação.

A atenção do receptor/usuário foi atraída para fora de si mesmo, devido ao estímulo das luzes da interface, a partir desse ponto, além da sua condição de receptor, o usuário passa à condição de leitor, estabelecendo uma mediação simbólica ou conceitual entre si e as luzes que emanam da interface. Essas luzes expressam diferentes cores, compõem formas diversificadas e configuram textos lingüísticos variados, que passam a ser lidos e ou decodificados pelo receptor-usuário (fig. 1).

Figura 1: Primeiridade, secundidade e terceiridade.

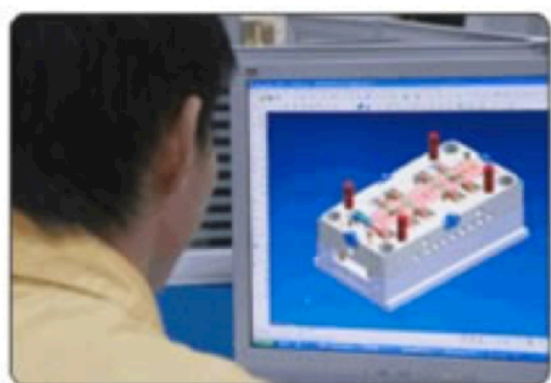

Primeiro há a sensação no receptor

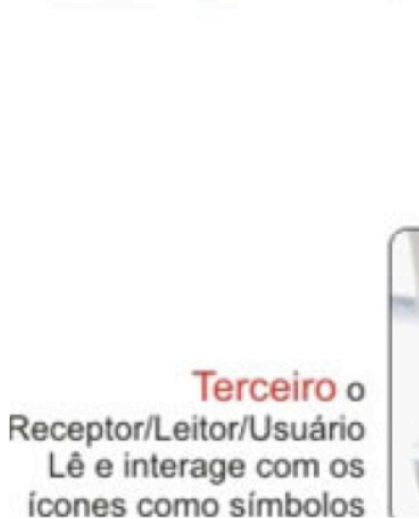
icones como simbolos
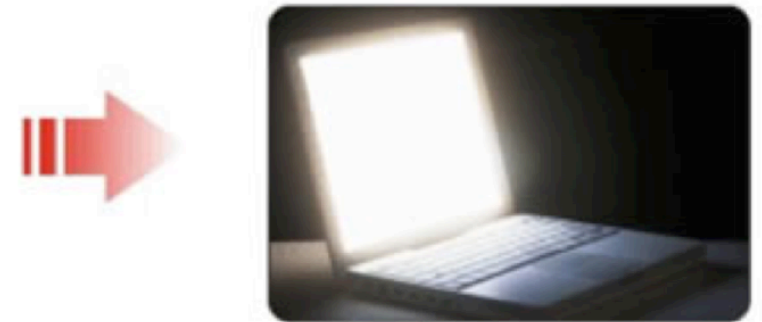

Segundo o receptor percebe a tela do video e seus estimulos luminosos

De acordo com essas categorias, todo sinal luminoso ou elemento escuro na tela é potencialmente um signo, portanto, os elementos que compõem o rótulo de um menu ou uma ontologia definida 
são signos. A categoria é um signo e a taxonomia também é um signo, ou seja, toda essa estrutura informacional é um signo. Enquanto trabalhamos com signos, estamos ocupados num processo chamado semiose, onde um signo leva a outro signo, que leva a outro signo e assim sucessivamente.

Segundo a metodologia descrita por Frederick Van Amstel (2005) para entender o processo na decisão de um clique, Peirce (1972) empregou as categorias universais para descrever o processo de objetivação, ou aquisição de um signo. O signo só estaria formado depois que a coisa referida pelo signo (externa) passasse pelas fases de primeiridade, secundidade e terceiridade, transformando-se finalmente no objeto (interno). Esse processo é o mesmo que se inicia na impressão inicial que o usuário tem da interface e termina com a formação de um modelo mental mínimo para ele iniciar o uso. A cada etapa de uso, a interface exibe novos signos e o modelo mental vai se tornando mais completo ou mais contraditório, dependendo da consistência da interface.

Cada signo dá origem a outro signo e assim por diante, atingindo o que Peirce chamou de "semiose ilimitada" (fig. 2).

Figura 2: Processo de semiose ilimitada que acontece em um hipertexto web.

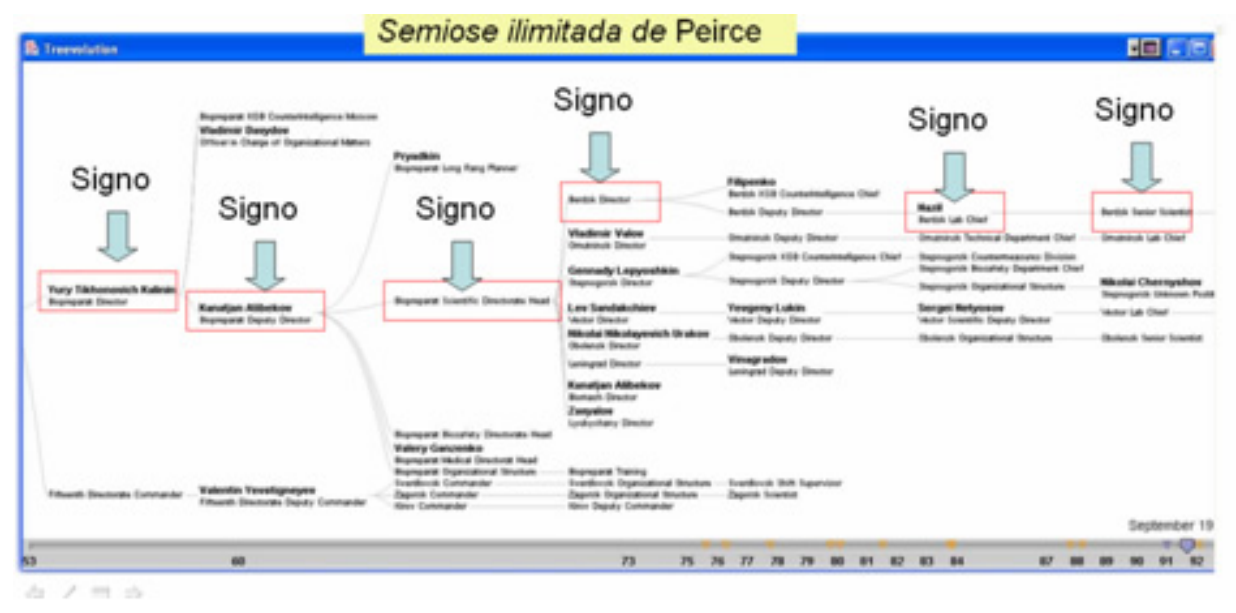

Peirce (1972) propõe que um signo é composto de três partes: (1) o representamen (que é a expressão material ou mental que suporta uma representação), (2) o objeto (aquilo que é representado ou referido pelo representamen, um referente) e (3) o interpretante (o produto mental decorrente da relação estabelecida pelo observador entre o representamen e seu objeto ou referente, aquilo que o representamen significa para alguém). A imagem luminosa de uma palavra é um representamen capaz de representar mais de um objeto e, também, propor interpretantes diversos de acordo com o conhecimento prévio e a capacidade de leitura e interpretação do leitor/usuário. No contexto interativo da web, além de seu significado lingüístico, uma palavra pode também representar um acesso a outros ambientes ou significar alguma das opções de menu de um site. Ao tomar uma palavra na tela de vídeo do computador como algo além de um signo lingüístico, um leitor/usuário decide acionar essa palavra com o cursor guiado pelo mouse, por exemplo, como se faz ao acionar ou "clicar" em uma opção de menu.

Ao escolher uma opção de menu, como representação ou representamen de um determinado link ou objeto, o leitor/usuário considera primeiramente que está diante de uma palavra, compondo um primeiro interpretante. Em seguida, lê aquilo que identificou como palavra gerando o segundo interpretante que é o significado da palavra. Além disso, de acordo com o contexto de apresentação da palavra e com outros indícios possíveis, como a mudança de cor ou de tonalidade dessa palavra, como reação ao contato com o cursor, o leitor/usuário compõe ou sobrepõe o terceiro interpretante ao primeiro e ao segundo, concebendo a palavra como algo além de um signo lingüístico, sendo também um signo interativo de acesso, seja um link ou algo semelhante. Depois disso, ao relacionar os interpretantes, (1) palavra, (2) significado da palavra, por exemplo, "salvar" e (3) signo de acesso, que atuam como representamens mentais:, surge o (4) quarto interpretante, estabelecendo uma síntese significativa como: "ao acionar a palavra 'salvar' com o cursor, tal ação resultará no registro de dados na memória do computador". 
No contexto da linguagem informática, de acordo com codificações previstas, há relações estabelecidas entre os significados de certas palavras, ou de certos ícones, e os indícios expressos em sua configuração, ou em seu contexto, ou em sua atitude. Essas relações estabelecem os sinais lingüísticos ou icônicos como chaves ou comandos para ações ou interações informáticas. O domínio do código lingüístico, ou do código icônico, e dos códigos informáticos, além da correta interpretação das características desses signos orientam a interação e a navegação no ambiente web.

A leitura ou interpretação eficiente dos signos digitais permitirá ao usuário experiências positivas e gratificantes no ambiente web. Para tanto, do ponto de vista da Semiótica, é necessário perceber os sinais digitais como representamens representantes de diversos objetos ou referentes e que são capazes de promover com sua aparição múltiplos interpretantes na mente do leitor/usuário. Caso o processo de semiose seja eficiente, a interação ou navegação no ambiente web será igualmente eficiente e gratificante.

Figura 3: Concepção triádica de signo aplicada na "decisão de um clique", segundo Van Amstel (2005).

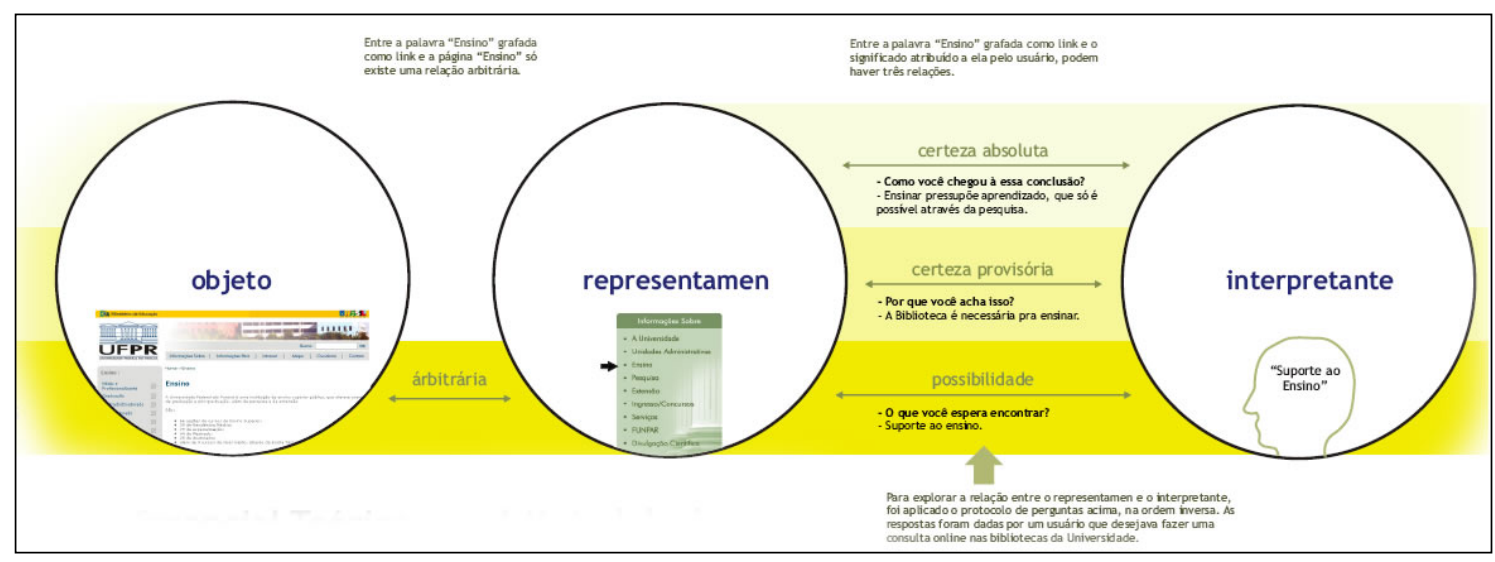

\section{Interpretação semiótica de um visualizador de e-mails}

Os e-mails enviados e recebidos em uma lista de discussão ou os posts de comentários de uma comunidade de prática são ricas fontes de conhecimento e informação que, geralmente, ficam esquecidas nos sistemas de correio eletrônico.

As palavras mais citadas em um conjunto de mensagens podem determinar uma tendência ou um interesse do grupo de pessoas que participa da lista de discussão em estudar ou discutir determinado assunto, que é apresentado e desenvolvido em uma linha do tempo. Outra aplicação dessa representação é a possibilidade de formalizar ou consolidar as palavras mais citadas pelo grupo ou pela comunidade e gerar a partir dessas palavras um tesauro ou um vocabulário temático. Dessa maneira, é possível manter atualizadas as palavras mais relevantes de uma comunidade e tornar ativa e relevante a participação da comunidade.

Há um processo de informação de conjunto, que é configurado na recorrência de palavras, de expressões e mesmo de características ou de sinais nos conjuntos de mensagens. As palavras, expressões e sinais recorrentes, ao serem descobertos e relacionados, compõem representamens cujos referentes não aparecem como objetos de cada uma das mensagens, das palavras ou dos sinais isolados. Essas novas representações promovem interpretantes diferenciados e reveladores sobre os pensamentos e valores do grupo de discussão em um dado período de tempo. Isso é, fornecem informações de conjunto que não são representadas nas mensagens, palavras ou sinais isoladamente (fig. 4). 
Figura 4. Objetos de análise que serão representados graficamente.

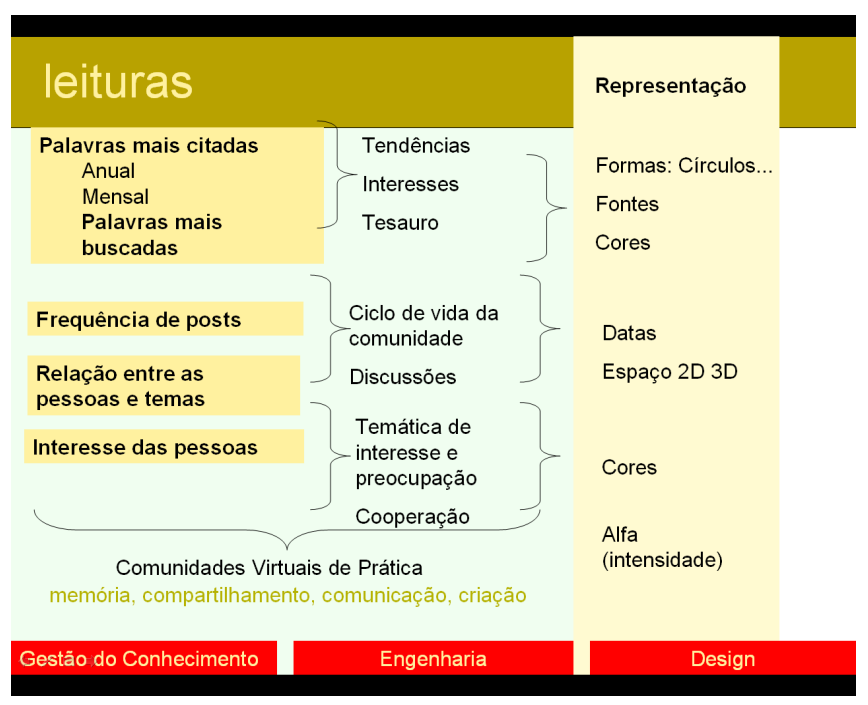

Há uma ênfase acentuada no aspecto semântico, desse modo, a interface que permite o levantamento e o relacionamento dos dados de conjunto (fig. 4) foi proposta para valorizar a navegação semântica, ou ontológica, com base nos sinais significantes ou signos. Todas as palavras (representamens) são designadas pelos próprios usuários, os quais que determinam o seu significado (objeto).

Neste contexto, a palavra "semântica" e a palavra "ontologia" recebem significações específicas da área de programação hipermídia de informática em rede. Assim, uma ontologia tem por objetivo representar formalmente o entendimento comum e compartilhado que as pessoas têm sobre uma área de negócio ou de conhecimento. Portanto, a ontologia estabelece uma informação de conjunto ou uma linguagem comum, por meio de relações semióticas. Essa linguagem ou representação é formada por um conjunto de termos que buscam cobrir todos os principais conceitos que melhor descrevem uma área de conhecimento e mostra o relacionamento entre esses termos (KOROWAJCZUK, 2002).

A representação mais simples de uma ontologia é a taxonomia, que começa com os termos que descrevem os conceitos mais abrangentes e essenciais, desdobrando-se nos termos subseqüentes derivados dos principais. Outra representação conhecida da ontologia é denominada "tesauros", a qual apresenta os relacionamentos entre os seus termos de forma mais abrangente que a taxonomia. Na prática, um tesauros representa de modo mais apropriado e econômico os objetivos de uma ontologia. No tesauros, os termos são associados a outros termos genéricos a outros específicos e a outros relacionados. Além disso, podem também ser associados os termos que apresentam conceitos similares (sinônimos) e os descritores e não descritores, que melhor representam o contexto no qual o termo do tesauros pode ser utilizado (KOROWAJCZUK, 2002).

A interpretação de uma taxonomia ainda depende do contexto de uso do site, da experiência do usuário com outras taxonomias e de seu lócus cultural, temos aí um problema de altíssima complexidade. Quando a ciência se depara com situações como essa, costuma recorrer ao isolamento dos fenômenos e à simplificação das explicações, em favor de uma maior compreensão.

A teoria Semiótica apresenta possibilidades para se lidar com a complexidade desse problema, porque trata da forma como são criados e interpretados os signos que compõem a taxonomia. Considerando que para Peirce (1972:p.94) um signo é "algo que, sob certo aspecto ou de algum modo, representa alguma coisa para alguém", o rótulo de uma categoria é um signo, a categoria também é um signo, a taxonomia é igualmente um signo e toda a estrutura informacional é composta por signos que contém significados e são capazes de promover processos continuados de semiose, nos quais um signo leva a outro signo sucessivamente.

\section{Ambiente de Apresentação - Interface de Visualização}

O módulo de visualização de e-mails (fig.5) possui dois ambientes, os quais são descritos a seguir. 
- Visão conteúdo (semântica), que apresenta os vocábulos representando assuntos abordados pela comunidade e relacionados com uma variante tempo, seja essa quinzenal, mensal ou anual. Os assuntos são dispostos verticalmente em relação ao período e apresentados na ordem decrescente de e-mails recebidos. No período em questão, os assuntos recebidos em maior número são diferenciados pelo aumento do número do corpo da fonte tipográfica e da cor.

- Visão rede, que apresenta a rede de relacionamentos também relacionados à variante tempo e ainda ao tema ou assunto. Mantém a mesma disposição gráfica que na visão conteúdo, mas utiliza uma transparência maior nas tonalidades das fontes dos assuntos listados. Essa transparência facilita a visão da rede que, no caso deste ambiente, possui maior ênfase. $O$ usuário poderá clicar em uma palavra para visualizar a rede de relacionamento daquele assunto, ou seja, as pessoas que durante aquele período de tempo colaboraram e trocaram conhecimentos sobre determinado assunto.

Figura 5: Tela principal do ambiente do visualizador de e-mail.

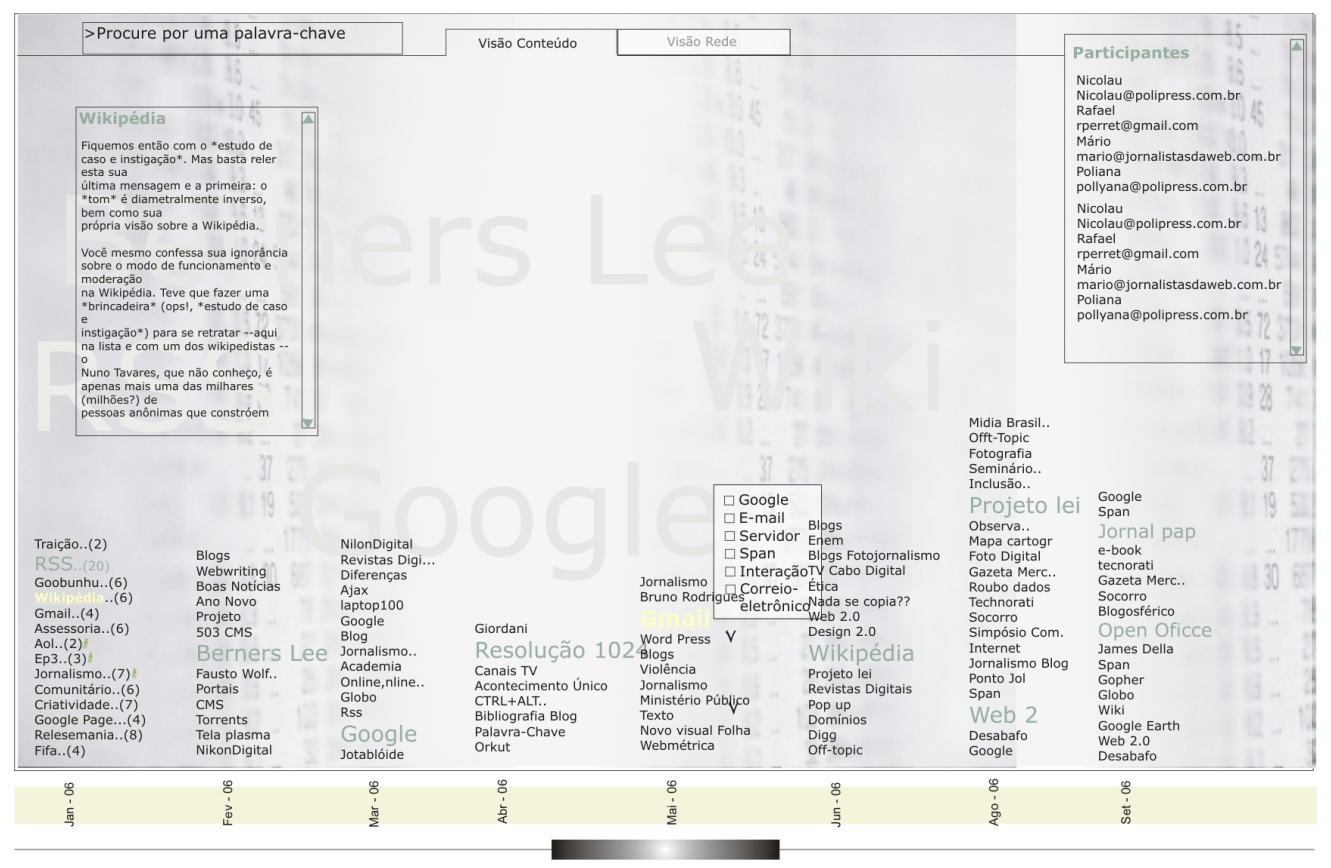

Há uma regra tipográfica que deve ser definida para a apresentação dos assuntos e, dependendo do número de posts encaminhados, uma fonte, uma cor e um corpo tipográfico específico serão apresentados. A escolha da fonte seguirá os fundamentos do design, adequados à mídia on-line (fig.6). Todavia, isso sobrepõe uma série de codificações morfológicas às significações lingüísticas das palavras, ampliando o campo semiótico com outras sinalizações. Uma vez que foram feitas seleções temáticas por recorrências de palavras e temas, esses conjuntos compõem novos representamens no processo de visualização, fazendo referência a objetos de conjunto que não seriam identificados nas mensagens individuais. Assim, o visualizador de mensagens compõe uma semiose própria e reveladora de aspectos significativos que se manifestam nas expressões de conjunto selecionadas e organizadas pela interface. 
Figura 6: Visualização dos assuntos (e-mails).

$\begin{array}{ll}\text { Traição..(2) } & \text { Blogs } \\ \text { RSS..(20) } & \text { Webwriting } \\ \text { Goobunhu..(6) } & \text { Boas Notícias } \\ \text { Wikipedia..(6) } & \text { Ano Novo } \\ \text { Gmail..(4) } & \text { Projeto } \\ \text { Assessoria..(6) } & 503 \text { CMS } \\ \text { Aol..(2) } & \text { BernerS Let } \\ \text { Ep3..(3) } & \text { Fausto Wolf.. } \\ \text { Jornalismo..(7) } & \text { Portais } \\ \text { Comunitário..(6) } & \end{array}$

O módulo da interface que possibilita a visualização das pessoas que enviaram comentários sobre um determinado assunto é denominado de "Rede de Pessoas por Assunto", permitindo a visualização de uma pessoa e os assuntos com os quais ela mais colaborou enviando posts para a lista.

Figura 7: Ícone A: uma pessoa na rede.

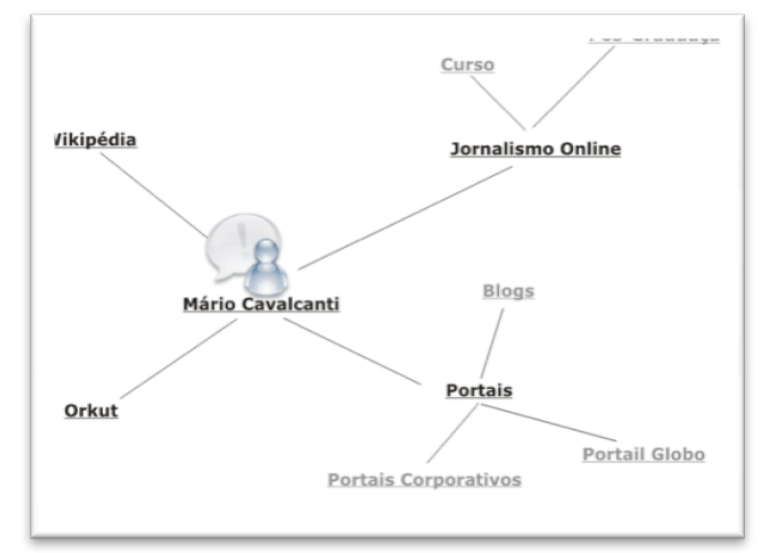

Figura 8: Ícone B - pessoas interligadas em rede.

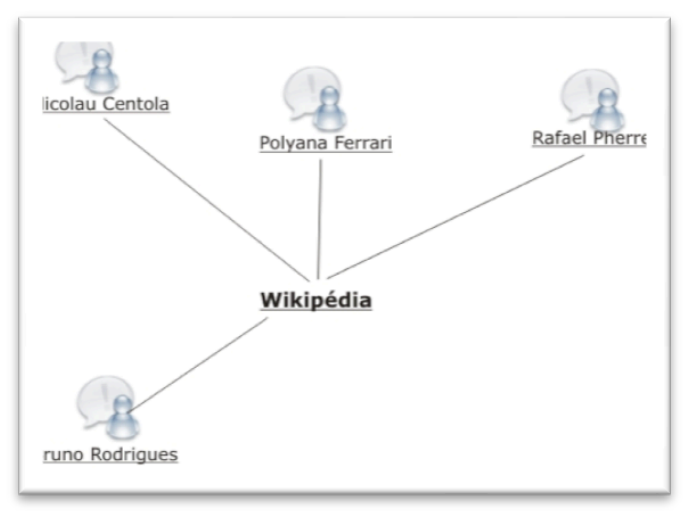

O ícone A (fig. 7) mostra as relações gráficas que representam uma pessoa na lista de discussão. $O$ ícone $B$ acima (fig. 8) apresenta as relações gráficas de pessoas ligadas a uma base de postagem. A identificação das pessoas é determinada pelos nomes e as bases também são identificadas por palavras. Contudo, as relações entre pessoas e bases são estabelecidas por sinais lineares que interligam esses elementos, estabelecendo relações espaciais a essas ligações. As informações obtidas por meio da interface visualizador permitem a configuração 
desses ícones como representamens de relações que constituem objetos de conjunto, os quais são imperceptíveis nas mensagens isoladas. As representações icônicas desses objetos propõem ao espectador/leitor um rico conjunto de interpretantes ou de significações.

De acordo com a classificação peirceana dos signos com relação ao seu objeto ou referente, há (1) os ícones, (2) os índices e (3) os símbolos, que são associados às três categorias fenomenológicas: primeiridade, segundidade e terceiridade, já referenciadas neste trabalho (GHIZZI, 2002).

O caráter icônico está ligado à primeiridade, que é determinada sob o domínio das sensações e dos sentimentos. Portanto, imagens e gráficos como os que foram apresentados acima (fig.7) são fundamentalmente icônicos, porque se relacionam com seus referentes de modo analógico ou apenas sensível. Já as palavras escritas ou os signos lingüísticos inseridos em meio aos elementos gráficos figurativos e espaciais requerem a intermediação de uma convenção ou de um código, indicando-os como simbólicos ou como símbolos. Por fim, as demarcações espaciais como as direções determinadas pelo posicionamento das linhas caracterizam índices ou signos indiciais.

É possível considerar a expressão luminosa e dinâmica que é projetada do vídeo de um computador, compondo uma interface eletrônica, como um objeto visual. A impressão sensívelafetiva que essa luminosidade provoca no espectador consiste em um fenômeno de primeiridade, indicando o conjunto luminoso como um ícone. O reconhecimento de que a sensação vivenciada foi decorrente da tela do vídeo é um fenômeno de secundidade, e o conjunto de elementos que relaciona a sensação do espectador com a expressão do objeto compõe um índice ou um conjunto de índices. O conjunto de associações estabelecidas entre os estímulos luminosos emitidos pelo vídeo e os dados da memória do, agora, espectador/leitor compõe um símbolo ou um conjunto simbólico.

De acordo com o tipo de associação, os símbolos indicam sua origem icônica, indicial ou tipicamente simbólica. Assim, a capacidade do espectador/leitor decodificar as palavras da interface depende previamente do conhecimento das convenções da escrita, determinando as palavras como signos simbólicos com relação ao objeto que representam ou ao referente a que se referem. Os símbolos decorrentes de associações por analogia ou semelhança morfológica, que consistem em relações de mera aparência, têm sua origem nos signos icônicos. Os símbolos que resultam de relações físicas e espaciais entre a parte e o todo, promovendo um sentido de continuidade entre o representamen e o objeto que representa ou entre o referente e ao que é referido, têm sua origem em signos indiciais ou índices.

Figura 9: Idéia inicial da interface: mapeamento estático de assuntos da lista de discussão "Jornalistas da Web" através do tempo (janeiro a setembro de 2006). Fonte: http://www.jornalistasdaweb.com.br.

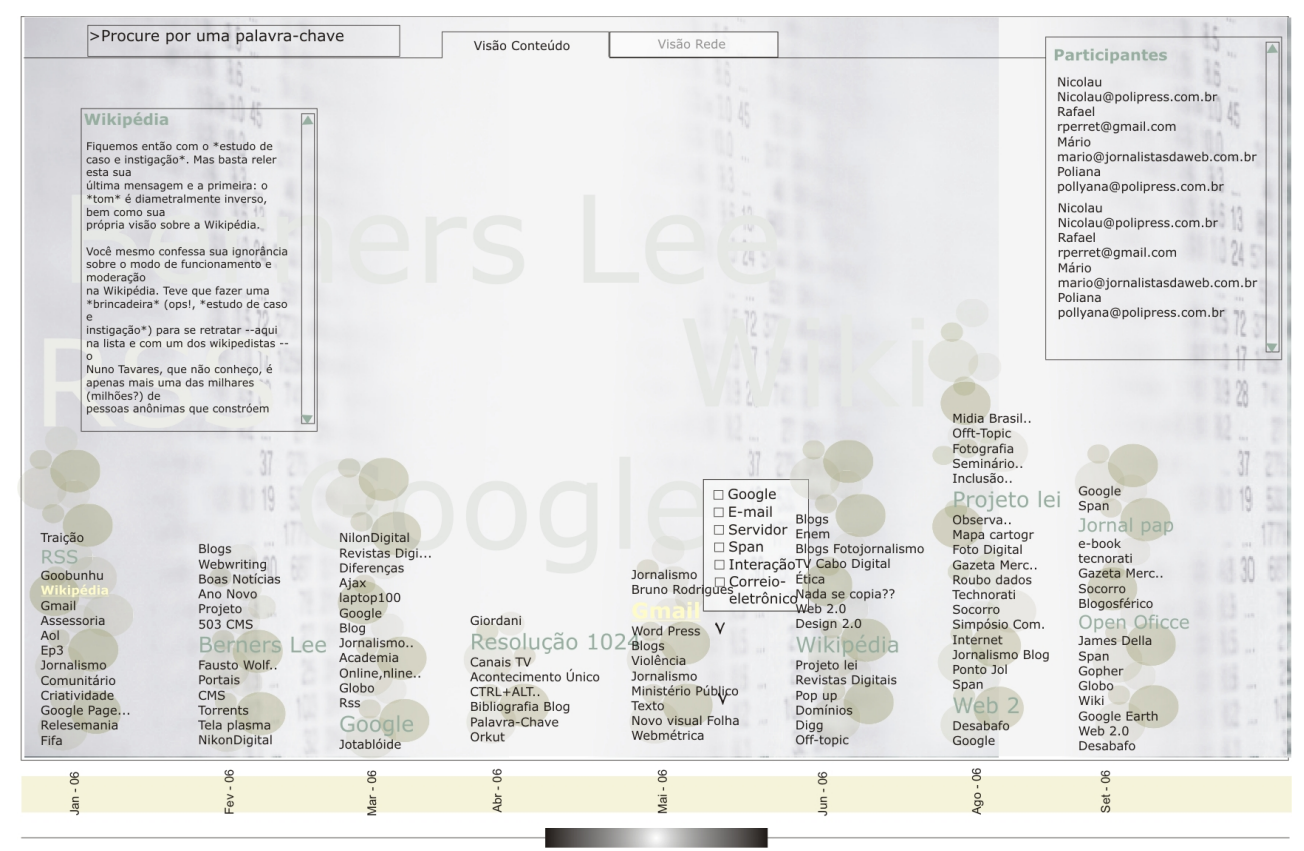




\section{Considerações Finais}

Um espectador/leitor/usuário de interface digital, humano ou tecnológico, para interagir de modo coerente no ambiente web, necessita ser sensível aos estímulos físico-luminosos produzidos pela interface e reconhecer que é externa ao seu corpo a fonte desses estímulos que lhe afetam internamente. Deve conseguir, também, estabelecer associações entre o que percebe e o que armazena na memória, para decodificar por convenção, por analogia ou pelas relações entre as partes e o todo as conexões simbólicas que permitem a leitura dos signos compostos e apresentados na interface. Além disso, deve ter condições eletrônicas e/ou motoras para interagir de modo coerente e produtivo com esses signos, de modo que possa acionar e manejar o sistema eletrônico-digital interativo.

A interface aqui apresentada, como um visualizador de e-mails, além de permitir ao espectador/leitor/usuário humano o acesso, a percepção e a leitura de mensagens, também, atua como espectador/leitor/usuário eletrônico que, ao ser orientado por usuários humanos, é capaz de perceber, reconhecer, associar, selecionar e armazenar por processos estocásticos dados de conjunto selecionados de acordo com critérios pré-estabelecidos, como o de recorrência ou os de temas e palavras-chave.

O produto da ação de um visualizador desse tipo é a composição imediata de representamens de conjunto, os quais seriam compostos com processos muito trabalhosos por um espectador/leitor/usuário-humano. Esses representamens suscitam objetos ou referentes impensados em primeira instância, promovendo para os espectadores/leitores/usuários-humanos interpretantes ou conhecimentos até então desconhecidos. Um visualizador é, portanto, um agente semiótico que reconhece, interpreta, seleciona e armazena dados, reconhecendo-os como signos ou informações de acordo com processos associativos restritos e pré-estabelecidos, entretanto, é capaz de reunir e organizar informações de conjunto com grande economia de tempo e resultados muito promissores para o desenvolvimento de conhecimentos sobre relações e valores de conjunto em grupos interativos no ambiente web (fig. 6). O fenômeno da semiose ilimitada, observada por Peirce, no estudo dos signos é facilmente identificada no ambiente hipertextual, dessa forma ressaltamos a importância dos estudos da semiótica com a finalidade de entender com mais profundidade o campo da percepção.

\section{Referências}

GHIZZI, E. B. 2002. O processo perceptivo e os significados urbanos em tempo de globalização. Galáxia: Revista Transdisciplinar de Comunicação, Semiótica e Cultura, v.3, p 235 - 239.

KOROWAJCZUK, A. 2002. Web Semântica - Projeto OntoWeb. Disponível em http://www.sbgc.org.br.

PAULINO, R. C. R. 2007. Representação Gráfica de e-mails em Ambientes de Colaboração: Uma forma diferente de apresentar a informação e gerar conhecimento. In: Anais do 7o ERGODESIGN 2007 - Congresso Internacional de Ergonomia e Usabilidade de Interfaces Humano Computador. Camboriú: UNIVALI.

PEIRCE, Charles S. 1972. Semiótica e filosofia. São Paulo: Cultrix.

PERASSI, R. 2005. Roteiro didático da arte na produção do conhecimento. Campo Grande: UFMS.

VAN AMSTEL, F. 2007. Uma proposta semiótica para a avaliação de estruturas de navegação. Disponível em:

http://usabilidoido.com.br/uma_proposta_semiotica_para_a_avaliacao_de_estruturas_de_nave gacao.html. Acessado em nov 2007.

\section{Sobre os autores}

Rita de Cássia Romeiro Paulino concluiu o doutorado em Engenharia e Gestão do Conhecimento pela Universidade Federal de Santa Catarina em 2011. É Mestre em Engenharia de Produção, Mídia e Conhecimento, pela Universidade Federal de Santa Catarina (1997). Atualmente é WebDesigner Sênior do Instituto Stela. Publicou 9 trabalhos em anais de eventos. Possui 1 software registrado e 4 artigos publicado em evento internacional. 
Richard Perassi Luiz de Sousa é Doutor em Comunicação e Semiótica pela Pontifícia Universidade Católica de São Paulo (2001), Mestre em Educação pela Universidade Federal de Mato Grosso do Sul (1995), Bacharel em Desenho de Propaganda e Licenciado em Artes Plásticas pelo curso de Educação Artística da Universidade Federal de Juiz de Fora (1986). Atualmente, atua como professor adjunto da Universidade Federal de Santa Catarina.

Francisco Antonio Pereira Fialho possui graduação em Engenharia Eletrônica pela Pontifícia Universidade Católica do Rio de Janeiro (1973) e em Psicologia pela Universidade Federal de Santa Catarina (1999), mestrado em Engenharia de Produção, Ergonomia, pela Universidade Federal de Santa Catarina (1992) e doutorado em Engenharia de Produção, Engenharia do Conhecimento, pela Universidade Federal de Santa Catarina (1994). 